\title{
Z przedwojennych podróży Anny Kowalskiej po Grecji. Wokół Opowiadań greckich i spuścizny rękopiśmiennej
}

DOI: http://dx.doi.org/10.12775/LC.2018.052

Drogi Panie, to Grecja nie z oleodruku, nie z muzeum i nie z nowych neonowych czasów. Ta którąśmy z mężem kochali.

(Dedykacja Anny Kowalskiej w egzemplarzu Opowiadań greckich dla Kazimierza Wierzyńskiego z 24 kwietnia 1959 roku) ${ }^{1}$

Streszczenie: Rękopisy Dzienników Anny Kowalskiej, dotychczas niewydane w całości, zawierają wiele opisów podróży - np. do Skandynawii przed II wojną światową, do ZSRR na przełomie lat czterdziestych i pięćdziesiątych. Nie zawierają natomiast opisów przedwojennych wyjazdów do Grecji i Włoch. Okazuje się jednak, że pewne fragmenty dzienników - lub zapiski pokrewne dziennikowym - znajdujemy pośród materiałów warsztatowych Opowiadań greckich (wyd. po wojnie). Książa ma wyraźny profil typowy dla literatury międzywojennej (psychologizm), sposób pracy autorki - przerabianie materiału zmierzające do kondensacji opisu i wydobywania rysów psychologicznych postaci - jest widoczny również w zachowanych redakcjach niektórych utworów. Materiały te, tak jak zapiski typowo dziennikowe w teczce z rękopisami Opowiadań, jak również niewykorzystane

* Dr, wykładowca na Wydziale „Artes Liberales” Uniwersytetu Warszawskiego i pracownik Muzeum Historii Żydów Polskich Polin. Autor prac z zakresu współczesnej literatury polskiej (m.in. na temat Tadeusza Konwickiego), komiksu (Maciej Sieńczyk) i historii filmu polskiego. E-mail: p.kaniecki@gmail.com

1 Egzemplarz książki Opowiadania greckie Anny Kowalskiej, wyd. 2, Warszawa 1956. Księgozbiór Kazimierza Wierzyńskiego (sygn. Wierz 176). Biblioteka Muzeum im. Adama Mickiewicza w Warszawie. Tu i dalej materiały archiwalne cytuję z zachowaniem pisowni oryginalnej, posługując się następującymi skrótami z dodaniem numerów kart: Kowalska ML 2146 = Kowalska, Anna (1924-1937). [Dzienniki]. Archiwum Anny Kowalskiej (nr inw. ML 2146, t. I: k. luźne, 3 zeszyty, część zeszytu; t. Il: zeszyt 7). Muzeum Literatury im. Adama Mickiewicza w Warszawie. Kowalska ML 2128 = Kowalska, Anna (między 1933-1949). [Opowiadania greckie]. Archiwum Anny Kowalskiej (nr inw. ML 2128). Muzeum Literatury im. Adama Mickiewicza w Warszawie. 
w książce próbki prozatorskie - tj. prawdopodobnie na bieżąco notowane, już w formie beletrystycznej, wrażenia z podróży - mogą być uznane za swoisty substytut zniszczonych albo niesporządzonych nigdy relacji z wyjazdów Kowalskiej do Grecji.

Słowa kluczowe: rękopis, Grecja, podróż, dziennik, Anna Kowalska

\title{
On Anna Kowalska's Pre-War Travels in Greece: Reflections on Opowiadania greckie [Greek Tales] and the Manuscript Legacy
}

\begin{abstract}
The manuscript of Anna Kowalska's Diaries, still not published in a complete edition, contains numerous travel accounts, e.g. from Scandinavia before the Second World War or from the Soviet Union at the turn of the 1950s, however, there are no accounts of her pre-war trips to Greece and Italy. It turns out that some parts of the Diaries, or some texts of that nature, were found among the sketches for the Opowiadania greckie (Greek Tales; published in 1949). The book displays certain characteristics typical of pre-war literature (such as psychologism); the writer's creative method, that is transforming the material in order to condense the description and bring out the psychological traits of the characters, can be also found in some of the author's drafts. These texts, both the diarystyle entries kept in the folder with the manuscript of the Opowiadania greckie and other pieces of prose, not used in the book, which were probably noted down during the trip, immediately in a fictional form, with travel impressions, may be considered some kind of a substitute for the destroyed or never written accounts of Kowalska's trips to Greece.
\end{abstract}

Keywords: manuscript, Greece, travel, diary, Anna Kowalska

powiadania greckie Anny Kowalskiej ukazały się jako książka w 1949 roku (poprzedzone publikacjami w pismach literackich), wyraźnie łączą się jednak z wyprawami autorki i jej męża do Grecji w okresie międzywojennym, w latach 1926-1927, 1934 i 1936 (Zawadzka 1996: 328). Nawet słabo znający życie prywatne Kowalskiej czytelnik mógł wysnuwać przypuszczenie, że pisarka opierała się na własnych obserwacjach. I nie tylko ze względu na główną bohaterkę-narratorkę prawie wszystkich opowiadań - Polkę, znająca kulturę starożytną (archeolożkę) i przybyłą na wyprawę do Grecji - oraz na przedwojenny czas akcji (w jednym z opowiadań mowa o wystąpieniu Mussoliniego; Kowalska 1966: 250). Ważna dla takiej lektury tomu, wiążącej Opowiadania i życie autorki, jest też chociażby postać towarzysza podróży, pojawiająca się w kilku tekstach, w tym w Natręcie. Mężczyzna ma na imię Jerzy - czyli tak samo jak mąż autorki, Jerzy Kowalski, profesor filologii klasycznej Uniwersytetu Jana Kazimierza, który napisał z żoną kilka tomów prozatorskich²,

\footnotetext{
2 Opublikowali wspólnie: Catalinę (1931), Mijaja nas (1932), Złota kulę (1933), Gruce (1936). Po śmierci Jerzego Kowalskiego (1948) ukazał się Gąszcz (1961). Kowalska przypomniała kilka spośród wspólnych mniejszych form
} 
a sam drukował w „Sygnałach” swój dziennik podróży (Kowalski 1936: 6; Kowalski 1937: 5). Notabene w jednym z przedwojennych autokomentarzy para wskazywała podróżowanie jako ważką inspirację dla swych prac literackich:

[... ] właśnie podróże to nie tylko poznawanie krajobrazu lub zabytków, ale to zawiłość losów ludzkich, istniejąca z pewnością i tu, nie tak jednak dostrzegalna, jak w punktach przetokowych: na pokładzie okrętu w nocy, w wielkiej hali dworca londyńskiego [...]. Kilkanaście zdań Greka, wracającego z Ameryki Południowej do ojczyzny, Szwedka, która jechała jako misjonarka do Afryki, Polaków, którzy uwikłali się w małżeństwa z cudzoziemkami i nie mogli już być szczęśliwi w kraju zamożnych żon ani w ojczyźnie ${ }^{3}$ : po kilkanaście takich zdań złożyło się na geografię naszego pisarstwa (Kowalscy 1937: 7; pisownia zmodernizowana).

$\mathrm{Z}$ drugiej strony, dwa inne opowiadania (drugie i czwarte w kolejności) mają innego narratora, trzecioosobowego, pokazującego intymne sytuacje postaci niezwiązanych z bohaterką pozostałych tekstów. Tak jakby Kowalska wprowadzała dla czytelnika „zastrzeżenie" do suponowanego autobiografizmu i sygnalizowała jednak fikcjonalny charakter całości. I zdaje się pogłębiać ten sygnał materia literacka wszystkich opowiadań - bardzo literacka właśnie, bo jakkolwiek oszczędna i nienarzucająca się, to uderzająca wycyzelowaniem kompozycji, sfunkcjonalizowaniem dobieranych z rozmysłem i odpowiednio charakteryzowanych postaci, podporządkowaniem szkicowanych sytuacji - refleksji.

Pokażę tę „literackość” Opowiadań w krótkiej analizie jednego z nich - Natręta. Jest ono dobrym przykładem jako bodaj najprecyzyjniej skomponowane spośród zgromadzonych w tomie. Nawet jeśli zdarzenia fabularne miały jakiś swój prawzór pozaliteracki, trudno nie zauważyć skali pracy przekształcającej ewentualne prototypowe zdarzenia: skondensowania środków literackich, przemyślnego doboru narzędzi kształtujących formę utworu. Przyjrzawszy się im, zaraz jednak powrócimy do pytania o autobiograficzne konteksty Opowiadań, sięgając do rękopisów Kowalskiej. Manuskryptowy punkt wyjścia autorki do ostatecznie osiągniętego kształtu tekstu okazuje się fascynujący tym bardziej, im bardziej nieoczywisty.

Tom, mimo że wyróżniony nagrodą ufundowaną przez Ernesta Hemingwaya ${ }^{4}$, nie doczekał

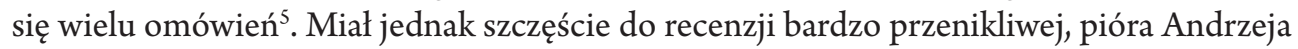

w tomie Trzy boginie (Kowalska 1966), umieszczając je jako swoisty aneks po wznowionych Opowiadaniach a wydrukowanych obok Safony (wchodzącej przez to w dialog z pierwszym z Opowiadań greckich) i trzech innych utworów. Tom jest swoistym literackim plonem podróży Kowalskich.

3 Por. uderzająco pokrewną zarysowanej sytuacji owych Polaków fabułę pierwszego opowiadania w omawianym tomie, Na statku.

${ }_{4}$ Była to nagroda dla dzieł polskich twórców ufundowana przez amerykańskiego pisarza, przyznana przez jury wybrane przez PEN-Club i Związek Literatów Polskich (skład: Jerzy Zawieyski - przewodniczący, Edward Kozikowski - wiceprzewodniczący, Bronisław Zieliński - sekretarz, Maria Bechczyc-Rudnicka, Mieczysław Jastrun, Wojciech Natanson, Antoni Słonimski, Jerzy Zagórski); otrzymali ją ex aequo Kowalska i Jan Józef Szczepański za Polska jesień („Nagroda literacka Hemingway'a” 1959: 6). Były to dość nieoczywiste wyróżnienia, zresztą także komentowane jako nietrafne (zob. Bratkowski 1960a: 11; polemika: Dąbrowska 1960: 2; odpowiedź: Bratkowski 1960b: 2). Są jednak oczywiście odnotowywane w różnych omówieniach, także popularnych (zob. np. Garlicki 2008).

5 L. M. Bartelski napisał nawet (1959: 18), na marginesie krótkiej recenzji Safony, że Opowiadania „należą w dorobku tej pisarki do pozycji niesłusznie przemilczanych przez krytykę", co nie jest jednak do końca prawdą, książka miała kilka recenzji, w tym dwie, cytowane niżej, bardzo pochlebne (Kijowski 1950: 5; Żukrowski 1950: 6; 
Kijowskiego. Krytyk zwrócił uwagę, że jakkolwiek układ opowiadań w tomie sugeruje szlak archeologicznej podróży narratorki i jej partnera, to bynajmniej nie przebieg trasy okazuje się w tej lekturze istotny: „Geograficzny porządek i zmienność miejsc ma uprzytomnić tylko jeden moment $[\ldots]$ : że podróż archeologa trwa. I to w sensie dosłownym i przenośnym. [... Treścią Opowiadań greckich nie są naukowe sukcesy podróżujących archeologów, ale ich nieoczekiwane przygody: mimochodem podpatrzone zdarzenia, zasłyszane opowiadania, odbyte rozmowy" (Kijowski 1950: 5). Tak naprawdę, stwierdza recenzent, nie tyle miejsca interesują Kowalską, ile Grecy („dziwność psychologiczna, specyfika pewnych środowisk - żeby tak powiedzieć - marginesów społecznych, - egzotyka obyczajowa”) oraz to, co dzieje się z nią samą - jako podróżnikiem i autorką poszukującą obrazu świata. Kijowski nie zatrzymuje się w zasadzie w ogóle przy Natręcie, analiza utworu potwierdza jednak te ogólne rozpoznania (z tym że jeśli chodzi o problematykę psychologiczną, ma ono o tyle wyjątkowy status, że snop światła, jakkolwiek dyskretnie, został raczej wycelowany w bohaterkę narratorkę, mniej w spotykanych Greków).

Opowiadanie poświęcone jest wędrówce bohaterki wraz z Jerzym do Lamii (wyruszają z bliżej nieokreślonej miejscowości) i zobaczeniu przez nich, niejako po drodze, przestrzeni, w której rozegrała się w roku 480 p.n.e. bitwa termopilska. Tyle że w wędrówce mają oni niespodziewanego, nieproszonego kompana, tytułowego natręta, obnośnego sprzedawcę, który ewidentnie psuje im - a przynajmniej bohaterce - humor i całą wyprawę. Nie pozwala nie tylko zwiedzać w spokoju, ale nawet fotografować, wciąż wchodząc w kadr.

Irytacja bohaterki narratorki koresponduje z innym gorzkim doświadczeniem. Albo raczej: złość i gorycz wzajemnie się, jak można sądzić, warunkują. Natręt jest też bowiem zapisem rozczarowania w zetknięciu z realnym miejscem, na temat którego miało się szczególne wyobrażenia, utrwalone przez tradycję kultury:

Znaleźliśmy się koło południa tam, gdzie stał mur focejski. Z radością odkryliśmy wśród gęstych oleandrów potok czysty i zimny. Bodaj czy nie z niego pił Leonidas owego lipcowego dnia ostatnią w swoim życiu wodę. Orzeźwiliśmy się i my u zdroju. $\mathrm{Z}$ daleka i z wysoka dochodzily dzwonki owiec. Ściana Kallidromosu czerniła się nieruchoma i po pięknej fali grzbietu ślizgały się małe obłoczki. Wzgórza, anonimowe w zielonej ciszy, nie wyróżniały się od innych, może tylko wiatr więcej kwiatów tu posiał. Rozmyślaliśmy nad tym, jak to trzystu Spartan zamieniło nazwę miejsca kąpielowego w rozgłośny od czynu orężnego i niezapomniany wyraz, co będzie zawsze trwożył najeźdźców (Kowalska 1966: 254).

Stwierdzenia dotyczące „niewyróżniania się” przestrzeni, wprost jej pospolitości, pokrewne są zdziwieniu innych podróżnych, nawiedzających historyczne miejsce. Podobny żal spotykamy chociażby u Mieczysława Jastruna, który powiada w swojej Podróży po Grecji: „nie ma tu nic niezwykłego. Wszystko jest inaczej i prościej, niż można było sobie wyobrazić. Nie ma nawet słynnego wąwozu nad morzem, gdzie bronili się i polegli Spartanie. Przewrót natury tektonicznej zmienił ich pozycje sprzed tysiącleci” (Jastrun 1978: 7-8). Autor jest

odnotujmy też jednak najbardziej niepochlebną, wręcz zjadliwą: Lichniak 1950: 7). Bartelski dodał przy tym opinię, ważną w kontekście uwag o precyzji języka artystycznego: „Cechuje je prostota i rzeczowość, są niemal kronikarsko oschłe, ale jakaż za to w nich znajomość ludzi!"; por. wyrażone przez krytyka w innym miejscu zdanie: „Anna Kowalska jest małomówna, oszczędna w słowach i gestach. W jej pisarstwie ta oszczędność przechodzi niemal w ascezę. Każde zdanie zostało wypracowane tak, że wydaje się ostatecznym w swej zwięzłości" (wstęp do wywiadu z pisarką: Bartelski 1957: 3). 
zresztą jakby ostrożniejszy w sądach niż Kowalska (Kowalscy?), bo w Opowiadaniach greckich znajdujemy po prostu zanegowanie wąwozowego charakteru tego miejsca w górach Ojta. Narratorka Kowalskiej stwierdza jednoznacznie: „wąwóz termopilski nie był wąwozem"; zaznacza przy tym co prawda zmiany terenu na przestrzeni stuleci - morski brzeg się cofnął, koryto Sperchejosu się wydłużyło - niemniej jednak określa charakter miejsca bez jakichś wątpliwości: było ono „jedynie drogą ograniczoną z jednej strony pochyłością stoków, z drugiej Zatoką Malijską, a właściwie szerokim jej zalewem” (Kowalska 1966: 255). A jeszcze ostrzej wypowiada się na ten temat opowiadaniowy Jerzy: „I David nie wiedział, czym jest wąwóz termopilski, skoro malując bitwę pod Termopilami upozował Leonidasa u zbiegu dwu skał nachylonych ku sobie...” (ibid.).

Żal, poczucie nieomal oszukania, skumulowane i najbardziej chyba widoczne w tym punkcie opowiadania, obecne są jednak w całym tekście, z odpowiednio dozowanym natężeniem. Jeśli przyjrzymy się opisom miejsca, dostrzeżemy, że tonacja poszczególnych odsłon topografii w narracji pierwszoosobowej jest powiązana z nastrojem bohaterki, to psutym, to na chwilę poprawiającym się. Jak u Wokulskiego, rozglądającego się po widowni na wyścigach i szukającego Izabeli, nieznajdującego jej i zniesmaczonego otoczeniem, odnajdującego ją wreszcie i po rozmowie z nią naraz zachwyconego wszystkim, co widzi (rozdział XIII Lalki). Podobnie w Natręcie wrażenia głównej postaci nieustannie to zabarwiają, to poszarzają obserwowany przez nią świat.

Już na samym początku utworu mamy zakreśloną tę perspektywę psychologiczną. Poznajemy bohaterów, kiedy siedzą przy oknie „zziębnięci i niechętni” i dowiadują się, że nie mają połączenia autobusowego. Nie czują się komfortowo, ale ten stan rzeczy zmienia się:

Gospodyni nie była przyjemna, a pokój zimny i brudny. Zarzuciwszy plecaki na ramiona i zaplaciwszy wyszliśmy na drogę. [...]

Za wsią od razu nabraliśmy humoru, mimo że gęsta biała mgła zakrywała przed nami świat; szliśmy jakby po dnie jeziora.

Ktoś biegł szosą, ktoś nas doganiał (Kowalska 1966: 250).

Pojawiający się handlarz dołącza do wędrujących. Po przytoczeniu dialogu z mężczyzną narratorka stwierdza: „Zaciążył mi plecak, a droga wydała mi się nieponętna”.

Potem naraz następuje jakby próba skupienia się bohaterki na czymś innym:

W tej chwili zobaczyłam na pagórku młodego pasterza wspartego na zakrzywionej pasterskiej lasce. Ukazał się niespodzianie, jakby cudem ożywiona postać ze starożytnej wazy. Smukłość chłopca, wdzięczny ruch, a także idealnie prosta linia nosa i loczkowaty zarost objawiły się nam jako tajemnice ciągłości i trwania typu greckiego.

- Pójdziemy górą, zrobimy parę zdjęć - powiedziałam. Komiwojażer popatrzył z wyrzutem: - A ja?! - Pan sobie odpocznie (ibid.: 253).

Scenka z młodzieńcem rozwija się dalej, w miarę jak wędrowcy idą pod górę. Narratorka obserwuje „pięknego pasterza” rozmawiającego ze starcem, który „jak prorok miotał się na górze”, kiedy jednak Polacy podchodzą do tej pary - „z zawstydzeniem”, jak mówi narratorka, konstatują, że rozmowa toczy się wokół cen bawełny i tytoniu. Znamienne, że niemiłe to odkrycie nakłada się na moment usłyszenia głosu „natręta”. Mężczyzna krzyczy i pokazuje ręką (w której trzyma jajko), gdzie powinni iść, żeby się z nim spotkać. 
I znowu: dopiero ucieczka od niego przynosi chwilowe ukojenie. Spokój zostaje wyakcentowany dzięki wzmiance o wyglądzie miejsca, w którym bohaterowie się znaleźli („[... ] byliśmy sami. Ścieżka wiła się kapryśnie po zboczu góry. Pod naszymi stopami rodziła się wiosna, niebo kwitło młodą jasnością”; ibid.: 253-254), stanowiącej wstęp do większej partii opisowo-refleksyjnej - cytowanego już fragmentu o „czystym i zimnym” potoku, z którego być może pił Leonidas, i o czerniącej się ścianie Kallidromosu. W akapicie tym, przypomnę, widać pewne sygnały zwykłości miejsca, uniezwyklonego przez wybitne wydarzenie, uwagi te jednak są wtopione w nastrojową narrację, wyliczającą kwiaty, barwy przedwieczerza, światła odległej Lamii, wymowa jest jak najbardziej pozytywna.

Tonacja zmieni się, oczywiście, kiedy podróżnicy znajdą się nad zatoką, gdzie czeka „dręczyciel” - jak określa go na tę okoliczność narratorka. Pejzaż odmalowany zostaje takimi słowy:

Od morza pędził wiatr i pokładał trzciny na bagnie, coraz to zrywało się ptactwo błotne, tam gdzie niegdyś tonęli Persowie. Zatoka umierała opodal drogi. Zeschłe trzciny i wysokie trawy moczarów bieliły się jak kości i szeleściły smutno. W całym świecie młodych blasków i miękkiej nowości jedynie zatoka trwała w zimowej śmierci (ibid.: 254-255).

Nagromadzenie metafor tanatycznych, określeń odsyłających do sfery śmierci („,umieranie” zatoki, „zimowa śmierć”, zeschłość trzcin, ich kolor, przypominający narratorce kości), zdynamizowanie opisu rejestracją ruchu elementów przyrody (wiatr pędzi, pokłada trzciny; ptactwo zrywa się), wreszcie wrażenia akustyczne (szelest trzcin i traw, domyślny wizg wiatru, łomot skrzydeł „ptactwa błotnego” czy plusk towarzyszący odrywaniu się ptaków od tafli wody) - czynią fragment wręcz modelowym przykładem opisu katastroficznego. A to właśnie w tym momencie pada cytowane wyżej stwierdzenie, że „wąwóz” jest w zasadzie po prostu drogą ograniczoną pochyłością stoków. Ekspresyjne ujęcie zatoki przygotowuje zatem werbalizację rozczarowania widokiem miejsca stoczonej przez Spartan bitwy.

Czerwono-czarny akwedukt, młyn zaniedbany, walące się mury - jakież to wszystko niezrozumiale zwykłe i niepodobne do uroczystej zjawy historii - podsumowuje narratorka ostatnie chwile pobytu w tej przestrzeni. - [...] Wystraszył nas pies owczarski, a gadulstwo komiwojażera obrzydziło nam wąwóz termopilski, historię i przedwiosenny wieczór (ibid.: 256).

Kowalska buduje więc w narracji sinusoidę samopoczuciową bohaterki narratorki, uzależnioną od obecności „natręta”, „dręczyciela” i rzutującą na sposób, w jaki prezentowane jest miejsce, oraz na przekaz intelektualny - „odczytanie” tego miejsca. Psychologia bohaterki organizuje sposób postrzegania przez nią i pokazywania odbiorcy, komentowania - niemalże po iwaszkiewiczowsku - przestrzeni ${ }^{6}$.

Konstrukcja przestrzeni, zdarzeń przedstawionych, postaci wyznaczana jest wyraźnie przez prawa modelu prozy psychologicznej. To ten model, zakorzeniony $\mathrm{w}$ okresie

\footnotetext{
6 Na temat refleksyjnego aspektu pejzaży w prozie autora Brzeziny: Speina 1998: 60-73. Podobieństwo jest oczywiście ogólne (u Iwaszkiewicza na obrazach przyrody jest nadbudowywana refleksja filozoficzna o charakterze egzystencjalnym), niemniej zasada relacji między obserwowanym przez bohatera światem przedstawionym a psychologiczną tonacją jego przemyśleń zdaje się pokrewna.
} 
międzywojennym ${ }^{7}$, kształtuje świat przedstawiony. Kowalska, chcąc ukazać mechanizmy psychologiczne (według swojej wiedzy czy wiary), komponuje tekst o bardzo wyrazistej strukturze, stricte literackiej. Literackość kompozycji niejako neutralizuje warstwę poetyki najbardziej w odbiorze tej małej formy prozatorskiej się narzucającą - przywodzącą na myśl gatunki niefikcjonalne.

Pracę warsztatową autorki dostrzegł już Kijowski. We wnioskach recenzyjnych „demaskował” - jak sam się na pół żartobliwie wyraził - narratora-archeologa (narratorkę-archeolożkę) „jako pisarza krążącego po wymyślonym przez siebie świecie w poszukiwaniu eksperymentu [literackiego]” (Kijowski 1950: 5). I stawiał tezę, że tom jest „artystycznym pamiętnikiem, warsztatową relacją pisarza zmagającego się z przyrządzeniem surowego materiału do ukształtowania go we własny i tym razem już »dosłowny« obraz świata” (dodawał skądinąd krytycznie - odnotowuję tylko dla porządku tę uwagę z warstwy opinii recenzenckiej: „Ale tego obrazu tu jeszcze nie ma”; ibid.). Na kwestię „wymyślonego świata” i „surowego materiału” rzucają pewne światło rękopisy autorki.

Długo wyczekiwany wybór dzienników Kowalskiej z 2008 roku (tylko, niestety, wybór) nie dał odpowiedzi, ile spośród książkowych greckich zdarzeń mogło być opartych na wypadkach, które faktycznie przydarzyły się pisarce, których była świadkiem czy o których słyszała podczas swoich przedwojennych wypraw. Nadzieje na możliwość ewentualnego zderzenia Opowiadań czy innych śródziemnomorskich utworów autorki i samych rękopisów diarystycznych rozwiała Julia Hartwig w przedmowie do Dzienników, stwierdzając twardo, że Kowalska „nie pozostawiła [... żadnego dziennika swych podróży” (Hartwig 2008: 6).

Faktycznie, jeśli sięgnie się do źródła edycji (Kowalska ML 2146), okazuje się, że zeszytów z drugiej połowy lat dwudziestych i z lat trzydziestych niestety pisarka nie pozostawiła kompletnych. Czasem znajdujemy zamiast zeszytów wręcz tylko luźne karty z wybranymi zapiskami refleksyjnymi (wypadek części I dzienników: 9 kart luzem), a jeśli zachowały się bruliony, tj. jeśli autorka je zachowała $\mathrm{w}$ formie zeszytu, brakuje niektórych kart albo - co jeszcze bardziej daje do myślenia - ich fragmentów. Zeszytów do prowadzenia dzienników, a i różnych notatek czy prac warsztatowych miała też Kowalska z całą pewnością więcej, niż pozostało.

Zwłaszcza zeszyt 2 (ibid.: k. 10-54) - zachowany w postaci zwartej, ale z wieloma wyrwanymi kartami - mógłby być świetnym materiałem odsłaniającym zainteresowania Kowalskiej Grecją i Włochami, ponieważ jest to brulion za rok 1927, a wtedy właśnie autorka odbywała podróże nad Morze Śródziemne. Zawiera jednak tylko kilka zapisów związanych z tym obszarem, i to głównie chyba notatek z lektur czy przemyślenia na ich podsta-

\footnotetext{
7 Natręt, jak i całe Opowiadania greckie stanowią dobry przykład kontekstowy dla wywodu J. Speiny (1998: 126-153) o niejednoznaczności cezur epok literackich 1918 (1932)-1948, względnej ciągłości artystycznego procesu przedwojennego. Przykład ten zresztą jest tu interesujący i ze względu na okres powstawania tomu rozciągnięty między końcem lat trzydziestych a powojniem, o czym niżej. Związki Opowiadań z Dwudziestoleciem podkreślał w swojej recenzji nieprzychylny ani tomikowi, ani międzywojennej prozie Aleksander Jackiewicz (1950: 7). Przy czym związki te widział krytyk po prostu w "zacieraniu hierarchii zagadnień na rzecz spraw małych, jednostkowych, nietypowych" i „ udziwnianiu i tragizowaniu [...] codzienności, wyolbrzymianiu błahych problemów do kształtów potwornych, wobec których malały sprawy naprawdę wielkie i naprawdę tragiczne".
} 
wie. Niektóre zapiski, typowo notatkowe, z drugiej połowy zeszytu, mają swoje nagłówki/ tytuły (czasem podkreślone, czasem nie). Na przykład na k. 32r znajdujemy uwagi:

\section{Kobieta.}

Admees [?] - dziewica

Starożytne bohaterki zachowywały piękność dłużej niż czas trwania rzeczywistej młodości. Helena, Penelopa, Klytaimestra. [...]

Na k. 33r (nagłówek „Bóstwo”): „Delfin, symbol Afrodyty, Nautik [?] i Posejdona [...]” (dalej podobne krótkie zapiski o nimfach). Na k. 34r notatki m.in. o cykadach („, [... Cyk. były początkowo ludźmi [...]”). Na k. 35r („Śmierć”): „Miód z mlekiem zmieszany, zmarłym na zalewkę[?] / Wczesna śmierć uchodziła za karę bogów [...]”. Na k. 36r krótka notatka: „Wyspa Aiolosa była dokoła obwiedziona miedzianym murem (? gładka ściana skalista) / mleko[,] wino i miód + [nieczyt., napój?]”. Na k. 37r: „Znajomość morza u Kretejczyków, Kronos nad Amnisos [...]”.

W zeszycie znajdują się też wpisy dotyczące pracy intelektualnej:

Muszę przyznać się, że przestałam wierzyć w swą siłę, w swą odrębność. Rzucam się z gorączkowym pośpiechem na zajęcia domowe, godzinami myślę, jak będzie wyglądało nasze przyszłe mieszkanie, marzę o nowej sukni. Widzę pięknie urządzone wnętrza, widzę ojca pięknie, starannie ustrojonego. Zresztą pustka $\mathrm{w}$ [?] myślach, uwaga zaprzątnięta błahostkami. A Homer? Odbywam lekcję sprzymusu, bez zajęcia. Nie mogę zdecydować się na przerwanie lekcji - nie mam energji wziąć się do rzeczy (Kowalska ML 2146: k. 11).

Plan na dzisiejsze popołudnie.

lgodzinna lektura Homera

lgodzinne czytanie perjodyków.

lgodzinne czytanie naukowych ks.

lgodzinne pisanie. [po lewej stronie karty, oddzielonej pionową kreską, ołówkiem: „1/2”]

Niczego nie kupować (ibid.: k. 24).

Nie ma prawie w ogóle impresji z pobytu. Uwagi z k. 31r - jeśli faktycznie odnoszą się do Grecji - należą do nielicznych wyjątków:

Morze

Morze: koloru fiołków, ogniste, podobne do powietrza, niebieskie[,] czarny bałwan, marmurowo-błyszczące, potwornie, wielkie, koloru wina, zmarszczka czarna, siwe, o wielkiej głębi, rybne, wiele jęczące[,] po burzy wyrzucające na brzeg ziele morskie / algi

W kolejnych zeszytach - wybrakowanych ${ }^{8}$ - refleksów greckich jest również śladowa ilość.

8 Z zeszytu 3 pozostało 16 kart. Zeszyt 4, za 1929, zachował się w postaci zwartej, ale znowu z wieloma kartami wyrwanymi. Jako część 6 tomu I dzienników funkcjonuje jedna karta bifolium. Zeszyt 7 (sygn. 2146, t. 2), za 1936, ma dopisek na okładce: „Zachować ten zeszyt”. Zob. Kordaczuk 2017: 234. 
W zeszycie 5, na k. 147r, z różnymi wpisami (data tylko przy pierwszym: 30 IV [1934]; drugi, niedatowany, odgrodzony kreską), znajduje się zapis z postanowieniem na wyprawę oraz z niezidentyfikowanym przeze mnie cytatem:

W podróży po Gr. wprowadzić gorgiaszowe określenie pojęć (jako tego co ludziom komunikujemy) różne od przedmiotów realnie istniejących. „Pojęcia tworzą jakości przedmiotów przenikające z zewnątrz. Nie wyraz czyni wyrażalnem to co jest nazewnątrz. Jeśli nawet pojęcia są realne, to są one różne od realności”.

Zdecydowanie najdłuższy zapisek poświęcony Grecji znalazłem w zeszycie 4, nosi datę 10 IV [1931], obejmuje aż dwie i pół karty (k. 90-92). Jego przetworzona wersja, znacznie skrócona i nawet pod inną datą (15 IV 1931), znalazła się pośród niektórych zapisków wcześniej przez Kowalską publikowanych jako Fragmenty dzienników w tomie Nimfa. W tej wersji drukowanej brzmi on:

Rozmowa z J. o Grecji. Bolesna rozmowa. Tak jakby to, że w Grecji czułam się szczęśliwa, było ciężkim przewinieniem. Pokłócić się o lwa w Cheronei! Czułam za plecami tego lwa i pobojowisko, ale wolałam patrzeć na granatowy śnieg Parnasu (Kowalska 1958: 118-119).

W dzienniku zapisek (o ile to ten sam) ${ }^{9}$ zaczyna się od słów:

Cały wczorajszy wieczór pływał po morzu greckim. Książka Laczetellia o Grecji obudziła mię. Nie powinnam się niecierpliwić ani martwić, że J. powstrzymał moje wynurzenia. Moja wina, że o tem mówię. Zawsze przyłapuję się na tem, że zbyt ufam bezpieczeństwu. Powiedziałam: gdyby tylko istniał ten fakt, że w Grecji czułam się szczęśliwa, mam prawo wybrać ją i pisać o niej. Na to Jerzy: nawet w kuchni twojej matki czułaś się szczęśliwa zapewne. [... ] J. na moje oświadczenie[,] że w Grecji byłam szczęśliwa, zarzucił mi, że mało się ruszałam, zwiedzałam, że siedziałam na kamieniu (Kowalska ML 2146: k. 90).

Dalej sporo emocjonalnych uwag o Grecji („Samo słowo Grecja rozełzawia mię. Uczucie wypełnienia wszelkich życzeń, szczęśliwość przezroczysta i barwna, lekkość, zadowolenie seksualne nieumiejscowione i równocześnie głód tego nieba, tego posągu, uśmiechu tych posągów, kolumn, zrzuconych kapiteli”, k. 91), kończących się właśnie podobnie do kilku zdań zamykających passus z Nimfy:

[... ] ale to co mię najwięcej interesuje w życiu to sztuka, a co sprawia największą przyjemność to ziemia, morze, lasy - pustkowie. W Grecji jest to wszystko cudownie połączone. W Cheroneji wpatrywałam się w granatowy śnieg Parnasu[,] ale za plecyma czulam lwa i pobojowisko, tak samo w Delfach, Mykenach, na Krecie (Kowalska ML 2146: k. 92).

Wpis jest zakreślony (obramowany) ołówkiem. Wybrany do wydrukowania?

Tyle zastajemy materiału mówiącego o Grecji Kowalskiej pośród kart pozostałych po pierwszych zeszytach jej dzienników. Ten skromny materiał znajduje jednak swoje nieoczekiwane dopełnienie w rękopisach zgromadzonych w teczce dotyczącej Opowiadan greckich

\footnotetext{
9 Nie ma w zeszycie zapisku z datą 15 kwietnia. Na k. 93, 94 znajduje się zapisek z datą 14 kwietnia, na karcie kolejnej - 30 kwietnia. Ale podobieństwo wersji dziennikowej i drukowanej jest uderzające.
} 
(Kowalska ML 2128). Pochodzą one - a co najmniej ich część - z całą pewnością z okresu przedwojennego.

Pierwszy materiał w teczce jest taki, jakiego spodziewamy się, sięgając do tego typu manuskryptów: jedna z redakcji Wiernej stugi, intrygująca z punktu widzenia warsztatowego dla interpretatora sczytującego tekst $\mathrm{z}$ wersją drukowaną; widoczne są chociażby inne tytuły pierwszy brzmiał: „Rodzina Dory”, został przekreślony cienkopisem i zmieniony, odręcznie, na: „Parasolka z motylkiem” (Kowalska ML 2128: k. 1-7; dwie pierwsze karty i część k. 3 to maszynopis, od 11 wersu k. 3 - rękopis fioletowym cienkopisem).

Następny rękopis (ibid.: k. 8-23) to redakcja Ziarna szaleństwa, opowiadania z pierwotnym tytułem „Pelopidas” i mocno przepracowanego później ${ }^{10}$ (np. w pierwotnej wersji otwiera tekst uwaga: „Pisarze angielscy lubią ukazywać kobiety jako histeryczne stworzenia niewrażliwe na argumenty logiki ani zdrowego rozsądku[,] a mimo całej histerii i kaprysu trywialnie rozsądne").

Kolejne karty zawierają dwie redakcje Rekrutów $z$ wyspy Paros: rękopis, noszący tytuł „Rekruty paryjskie” (ibid.: k. 24-37), oraz maszynopis z poprawkami, z tytułem takim jak w druku (k. 38-46). W tej też wersji został opublikowany jeszcze przed wojną (Kowalska 1938). Na karcie 1 maszynopisu (Kowalska ML 2128: k. 38) widoczne jest, pod nazwiskiem autorki w lewym górnym rogu, rękopiśmienne datowanie: „3510 [poniżej:] 9.IV.38” (pióro, czarny atrament, dodatkowo zakreślenie czerwoną kredką). Po lewej czerwoną kredką i otoczone okręgiem: „4”. Miał być czwarty w tomie? W publikacji powojennej jest dziesiąty. Może to czwarta redakcja?

Tekst został potem (zapewne po wojnie) znacząco przetworzony: wydrukowana w książce wersja ostateczna ma bardziej zwartą kompozycję - znacznie skrócony został zwłaszcza wstępny obrazek rodzajowy, natomiast akcent postawiła autorka na impresyjnej scenie wypłynięcia statku, tu zresztą partie maszynopisowe nie różnią się już bardzo od wersji drukowanej.

Dalej znajdujemy materiał zatytułowany „Zigo” (ibid.: k. 47-51), który w ostatecznym kształcie ukazał się drukiem jako opowiadanie Popołudnie w Tirynsie. Materiał będzie głęboko przetwarzany, ukształtowany zostanie z mocniejszym akcentem na psychologię: ku obserwacji postaci drugoplanowych (niepojawiających się w wersji pierwotnej) i pełniejszej prezentacji losów, sposobu patrzenia na świat i nadziei na przyszłość - związanych $\mathrm{z}$ dyrektorem wielkiej fabryki ${ }^{11}$ - głównego bohatera, noszącego w ostatecznej wersji imię Mario (prototypowy Zigo nosił imię takie samo, jakim obdarzyła Kowalska jednego z bohaterów innego opowiadania, Idylla w Nauplii; Wiesława Kordaczuk - 2017: 212 - opracowująca archiwum Kowalskiej do katalogu rękopisów Muzeum Literatury, uznaje, że treść manuskryptu jest bliska nie tylko Popołudniu, ale także $I d y l l i)^{12}$.

\footnotetext{
10 Opowiadanie było drukowane w „Zeszytach Wrocławskich” w 1948, nr 1, treść nie uległa już zmianie w stosunku do wersji książkowej.

11 Ten motyw był obecny w Zigu, tak samo jak motyw prowadzonego przezeń baru i wielkiej miłości do Paulette - choć ta nie ginęła z rąk bohatera, jak dzieje się w Popołudniu.

12 Skądinąd Kordaczuk (2017: 211) odczytuje rękopisowy tytuł: „Żigo”. Wydaje się jednak, że Kowalska konsekwentnie zapisywała z kreską pośrodku dużą literę Z (por. np. w tym rękopisie k. 49, wers 8 od dołu).
} 
Rękopis ten prowokuje już jednak do domysłów na temat nie tylko czasu, ale i kontekstu powstania. Wersja brulionowa, zresztą dużo krótsza, wygląda jak zapis sporządzony wręcz na bieżąco w trakcie podróży - to świeże, właśnie dziennikowe zanotowanie tego, co autorka widziała danego dnia, mimo że od razu w trakcie pisania kształtowane po literacku i komponowane; zamykające tekst uwagi na temat obserwowanych mężczyzn mają ewidentnie charakter puenty:

Więźniowie przechodzili, witali się z chłopami. Zauważyłam, że mają inne twarze. Zamyślone i pokorne[,] właśnie takie[,] jakie widzi się u Tołstoja i Dostojewskiego. Dotąd widziałam inne twarze w konwojach więźniów. A może ci byli starzy tylko... (Kowalska ML 2128: k. 51).

Materiał ma dużo mniejszą zwartość konstrukcyjną niż wersja ostateczna (ograniczona do tego, co dzieje się w barze). Początek - mikroobraz samej wędrówki narratorki i towarzysza - zawiera też jeszcze inny symptomatyczny element: pojawiający się bez uzasadnienia beletrystycznego, ba, nie tylko nieumocowany w fabule, ale zupełnie niewyjaśniony, a więc mający, jak można się domyślać, charakter intymistyczny, motyw powrotu do miejsca, w którym było się kiedyś:

Wpadliśmy w ostatniej chwili, pociąg już [skreśl. „prawie”] ruszat[,] do [skreśl. „dlatego”] malutkiego przedziału 3 klasy. Wysmukły [skreśl. „męż”] robotnik w słomkowym kapeluszu ustąpił miejsca.

- Do Tirynsu jedziecie?! To wstąpcie do mnie na lemoniadę[,] mam bar przy stacji.

Starannie uprawne pola, wysokie trzciny i kamienne zwalisko grodu. Wysiadamy, dziękujemy za miejsca.

- Szlachetni są - chwali nas po homerycku grubas z wiankiem ryb na kolanach.

Ubawieni tym epitetem idziemy tą s a mą królewską drogą między cyklopie mury. I już odrazu żałuję[,] że tu jestem. Ci[ę]żej od cyklopich murów [skreśl. „jest”, „spoczywa”] przygniata mię czas. Istnieje chyba zmysł minionego czasu. Bo oto echo kroków w wartowni królewskiej przynosi mi przezwisko: głupia! Gdzie to dyonizyjskie porwanie owego dalekiego przedwiośnia[,] gdzie anemony i żółte selinusy, gdzie fijołki i irysy, gdzie są roztrwonione dni owych sześciu lat (Kowalska ML 2128: k. 47r, 48r; wyróżn. P. K.).

„Owe sześć lat” to może właśnie okres dzielący dwie greckie przedwojenne podróże Kowalskiej: tę z lat 1926 i 1927 od tej z 1934?

Na tym materiale, mimo że to połowa teczki, kończą się rękopisy utworów czy rękopisy związane z utworami, które znalazły się w wydrukowanym tomie. Kolejne urywki nie zostały spożytkowane w książce, a przynajmniej nie znajduję podobieństw. Są to teksty zapisane na kartach pochodzących z różnych notatników (najczęściej z takich, które miały perforację u góry kartek i z kartkami w szerokie linie lub czystymi). W katalogu rękopisów Muzeum Literatury Wiesława Kordaczuk (2017: 212) nazywa je „opowiadaniami i notatkami literackimi z podróży po Grecji”. Są to:

1. Materiał zatytułowany Droga do Mistry. Zaczyna się od słów: „Ledwie minęliśmy podmiejskie wille[,] jedno $\mathrm{z}$ nas powiedziało: nie zapomniemy tego popołudnia! [...]” (Kowalska ML 2128: k. 52-59). Obserwacje przestrzeni, widzianych ludzi - podane w czasie przeszłym, niekiedy w opisie mikroscenek pojawia się czas teraźniejszy; refleksje końcowe - w czasie teraźniejszym: 
Oczarowani i przerażeni patrzyliśmy się na niebo ciężkie od gwiazd. Ledwo że wyżej szczytów eukaliptusowych drzew płynęła szeroko rozlana Mleczna Droga[.] Tumany pyłu gwiezdnego niczem na drogach greckich wznosiły się nad nią. Patrzę na migotliwą barwną gwiazdę chcąc się ocalić i odnaleźć, ale zaraz dostrzegam inne mniejsze. I z szeroko otwartemi ustami dostrzegam - głębię i na chwilę mam jakby ogarnięcie ogromu świata[,] o kt. zwykle tylko wiem, że jest ogromny.

Przeraża mię to niebo, najeżdża jak tank najeżone gwiazdami, miażdżące, nie ludzkie, nie zwierzęce, nie roślinne, zabójczo mroźne i zabójczo rozżarzone... Metalowe niebo[.]

I czuję siłę tych gwiazd[,] których okiem niewidzę i ich sens nie człowieczy, obcy, własny, $\mathrm{z}$ którego jesteśmy wygnani.

I jakie to dziwne, że jestem, że jestem nie metalem, ale czlowiek [... ] (ibid.: k. 58-59).

2. Jednokartowy Epidaur (w lewym dolnym rogu ołówkiem: „Peloponez”) - scena ze spotkanym w ruinach teatru lekarzem, w szczególny sposób - literacki - spuentowana:

Gdy zeszliśmy[,] zbiegł pędem[,] przeskakując dwa trzy stopnie. Na dole znowu spojrzał na nas kontrolując nasz podziw.

- Zawsze zdumiewałem kolegów w szkole przy gimnastyce. U nas w Zagrzebiu ...

[Skreślone: „Jastrząb przelecial”] Ptak przeleciał między nami i zniknął w ruinach (ibid.: k. $60)$.

3. Kościótek przy Mykonos („Wiatry ekwinoscji ścinały grzywy falom, przechylały morze i okręty kładły na bok jak chore ryby[,] a wysepki podcinały jak bąki”); obserwacje miejsca oraz ludzi, m.in. przeglądających się w lusterkach malarek Francuzek (ibid.: k. 61-63).

\section{Latomje (ibid.: k. 64-65). Początkowe wersy brzmią następująco:}

Dęby korkowe, tymianek, lebioda, w ostach pachnące różowe [skreślone: „fiołki, które”] cyklameny. Pierwsze kwiaty jesieni. Mimo woli myślę o recenzencie[,] który irytował się[,] że zapominam[,] o jakiej porze roku piszę, bez złości pokazałabym mu na różowe kwiaty i poradziła powąchać, ale recenzenci nie mają czasu na szukanie fiołków po wyspach na $[\mathrm{M}]$ orzu [E]gejskim.

[... ] Patrzę na te przeróżne krzaczki[.] Z daleka ziemia świeci[?] nagością kuso[?] przyodziewają ją ozycjany i mięty, ale gdy siądziesz w cieniu[,] palce rozpoznają te najprzedziwniejsze zielska (ibid.: k. 64-65).

5. Tekst bez tytułu, zapisany ołówkiem, niezmiernie ekspresyjny, zaczynający się od słów: „W dolince dostrzegam narcyz. Biegnę do niego, kładę się i oglądam” (ibid.: k. 66).

6. Maraton, zaczynający się od słów (po skreśleniu: „Obeszliśmy długim”): „Ostatni dzień pobytu w Grecji. Jutro wylecimy w kilkunastogodzinny lot ku domowi [...]” (ibid.: k. 67-73). U dołu k. 70 (k. 4 według foliacji autorki) akapit piórem:

Sto słonecznych dni. Okrutne powroty do miejsc[,] które już przemieniły się w myślach w szczęśliwą nierealność. Oto leży Eubea[,] gdzie budowaliśmy dom i ogród. Oto oliwki, figi i wino. Szczęśliwe poranki [skreślone: „dnie”], dobre zmęczenie, odnaleziona niewinność w patrzeniu. Jeszcze raz zobaczymy nazajutrz ten kraj [skreślone: „który stał się ojczyzną”] tak jak dobrze jest go widzieć $[\ldots]$ [... 2 słowa nieczyt. $] \ldots \mathrm{z}$ chmur". 
Poniżej długa kreska, zamykająca wpis. Wersy rozpoczynające kolejną kartę (k. 71) zostały najprawdopodobniej sporządzone w innym momencie niż cytowany fragment - i zapisane ołówkiem, dopiero potem przechodzącym w pióro. Refleksje zostały spisane, można to stwierdzić z całą pewnością, w Grecji.

7. Materiał bez tytułu (ibid.: k. 74-76), przez Kordaczuk (2017: 212) nazwany: „O szczęśliwej rodzinie (obrazek z podróży z Trypolis do Argos)”, zaczynający się od słów:

Była to najszczęśliwsza rodzina. [skreślone: „jaką wi”] Są nagrody pokoju i sztuk [dla] licznych rodzin i za bohaterstwo, ale niema nagrody dla ludzi[,] którzy umieją żyć szczęśliwie. Może by je wtedy stracili.

8. Materiał bez tytułu - „O wyspie Samos (fragment i zakończenie)” (Kordaczuk 2017: 212; Kowalska ML 2128: k. 77-83; brak niektórych kart, na co obok luk w treści wskazuje foliacja autorki, numery zaczynają się od 3, mamy kartę z numerami 4 i 5 - k. 78, 79 - a później brak kart z numerami 6, 7, 8, 9, 10: karta 80 nosi nadany przez autorkę nr 11). Obfita w szczegóły relacja z nieprzyjemnej podróży statkiem i wędrówki po wyspie.

9. Notatka pod tytułem Paros (Kowalska ML 2128: k. 84-87), zaczynająca się od słów: „Zielona przezroczysta głębia płoszy [skreślone: „rozmowę”] słowa. Ostrożnie pochylam się nad skalistym brzegiem [...]”. Obserwacje miejsc i wspomnienie koleżanki, Beatki, zmarłej w wieku dziecięcym - której pamięć została niespodziewanie przywołana przez „niebiańską paradę zachodzącego słońca nad wyspą” (ibid.: k. 87).

10. Refleksyjny tekst pod tytułem Santorini (ibid.: k. 88-89), zaczynający się od słów:

Odwracam głowę i w oczy wlewa się niebieskość morza, siność horyzontu [nadpisane nad przekreślonym: „dali”] i szklistość [nadpisane nad przekreślonym: „przezroczystość”] nieba. Na skałach siedzi malarz Anglik [...].

11. Opisowo-refleksyjna notatka pod tytułem Sparta (ibid.: k. 90-94), zaczynająca się od przekreślonych słów: „Zaschła na kamień”, a dalej: „Zorane pole skamieniało w bruzdach, ziemia utraciła siły. Tylko osty żyły, bo kłuły, ale i osty były suche [...]”.

12. Materiał pod tytułem Sparta. mur. (ibid.: k. 95-96), zaczynający się od słów: „Rola stwardniała w skałę; ścierniska, korzenie, badyle skamieniały również. Nogi w sandałach potykają się o kamienie".

13. Materiał bez tytułu (ibid.: k. 97-98), zaczynający się od słów: „Sama gotuje, sama sprząta, sama usługuje. W czarnej jedwabnej sukience, w białym czepku i fartuszku przynosi półmiski”. To fragment większej całości: 9 i 10 karta według foliacji autorki (przy czym nie jest wykluczone, że była to część materiału 8).

14. Materiał bez tytułu (ibid.: k. 99-100), zaczynający się od słów: „Na całym obszarze dawnego miasta niema nikogo prócz nas". Opis nieokreślonych z nazwy ruin, zastanych w nich mozaik, malowideł z ich ścian.

15. Niedokończone opowiadanie na karcie bifolium, bez tytułu, z numerem „I” na początku, zaczynające się od słów: „Fibrenus zmętniał po długich deszczach ostatnich tygodni grudnia" (ibid.: k. 101-102, zapisana tylko pierwsza strona - 101r).

16. Notatka w formie bliskiej niektórym zapiskom z drugiej części zeszytu 2 dzienników: 
Amazonki

W Iliadzie - [skreśl. „bitwy”] amazonki bijące się w Azji.

Arktinos o Penthesileia

Achilles walczy z amazonką

Die Heraklessage lässt umgekehrt den Vorkämpfer der Griechen in das Land der Amazonen ziehen und dort das ganze Volk besiegen. [...] [poniżej również dwuwers w j. starogreckim (część cytatu?)] (ibid.: k. 103)

17. Zeszyt powojenny (ZWP Strzegom) z notatkami; napis na okładce przedniej: „ARYSTOFANES” (k. 104-143, dokładny opis zeszytu: Kordaczuk 2017: 212).

Cały ten materiał z drugiej części teki (poza ostatnią pozycją), a także nawet pierwsza redakcja Ziga pochodzą najpewniej z przedwojennych zeszytów Kowalskiej. Część wszystkich tych zeszytów została zachowana jako zeszyty stricte dziennikowe, a część była jakimiś brulionami warsztatowymi do pracy artystycznej. Sądzę - jakkolwiek to oczywiście tylko supozycja, nie mam jednoznacznych, a przynajmniej wystarczających dowodów - że Kowalska w trakcie pracy nad książką (po wojnie?) czy już podczas przygotowywań do jej pisania (jeszcze przed wojną?) przeglądała swoje bruliony i uznawała niektóre zapiski za materiał czy to do późniejszego przetworzenia (np. metodą wielokrotnego przepisywania tekstu, z jednej wersji do kolejnej) ${ }^{13}$, czy to jako tekst-inspirację do utworu - i przekładała je do teki z materiałami roboczymi Opowiadań ${ }^{14}$. A są w tece chociażby notatki z lektur ewidentnie pokrewne tym z zeszytów 2 czy 5, jak również karty takie jak emfatyczny zapis o wąchaniu narcyza (materiał 5) czy notatki gromadzące wiedzę na temat Sparty - one pochodzą z pnia diariuszowego, to dokładnie taki sam materiał, jak na kartach będących częścią dzienników. To zapiski robione w podróży czy krótko po niej. Do wysnuwania takiego domysłu skłania też intymistyczny charakter fragmentów Droga do Mistry, Maraton czy relacja samojska, a do pewnego stopnia także dokumentarny, opisowy charakter tekstów takich jak Sparta czy materiał 14.

Wypada uznać za trafną cytowaną już zwięzłą katalogową formułę Wiesławy Kordaczuk: „opowiadania i notatki literackie z podróży po Grecji”. To, co się zdarzyło - to, co widziała, czego doświadczyła Kowalska - zapisywałaby więc już od razu z pewnym ukształ-

\footnotetext{
13 Przepisywanie kolejnych wersji było, można sądzić, jej metodą pracy twórczej. Tak jak zresztą Marii Dąbrowskiej (Kowalska 1975: 5, 6; do tego stopnia, że Dąbrowska, jak wiadomo, przepisywała swój dziennik, rozpatrując zapiski pod kątem ich nośności literackiej, a zatem traktując dziennik - wbrew jego diarystycznej naturze - jak tekst artystyczny, zob. o tym Rodak 2011: zwłaszcza 345-373). W wypadku Kowalskiej przepisywanie wiązało się często ze skrótami, zob. np. uwagi Koradczuk (2017: 210) dotyczące rękopisu Safony. Por. uwagi z tego szkicu dotyczące np. Rekrutów z wyspy Paros.

14 Por. uwagi Wojciecha Żukrowskiego (1950:6) o prototypowych dla Opowiadań notatkowych „marginaliach wyprawy". Uwagi te można uznać za oparte na wskazówkach pochodzących z rozmów z autorką (jak wiadomo, Żukrowski utrzymywał w okresie powojennym bliskie relacje z Kowalską i Dąbrowską), zwraca uwagę informacyjny, a nie np. supozycyjny charakter fragmentu: „książeczka narodziła się z poszukiwań za dawną Helladą, kiedy autorka ze swym mężem, znakomitym filologiem przemierzała kamieniste ścieżki, tropiła przeszłość. Tymczasem dzień powszedni, współczesność krzykliwą i niespokojną falą wdzierała się w badania archeologiczne. [...] Natarczywe życie zapełniało notatniki otwarte na przyjęcie okruchów przeszłości. Po kilku latach, gdy autorka natrafiła na owe marginalia wyprawy, przekonała się, że w dawnych brulionach życie nie ostygło, wrze i urzeka swoją zmiennością. Nie scukrowało się, jak figa. Lata sprawiły tylko, że fakty pogłębiły się, zyskały na plastyce. Stały uszeregowane w logiczne całości, jakby domagały się utrwalenia w opowiadania. Kusiły pióro".
} 
towaniem, przetworzeniem. W trybie interpretacyjnym można nawet chyba dopowiedzieć śmielej: że niektóre zapiski, sporządzane na bieżąco w trakcie podróży czy krótko po niej, były pisane już jako pierwsza wersja zamyślanego tekstu artystycznego (stąd ze śladami jeszcze typowych dla diariusza zdań, elementami wziętymi z doświadczenia autopsyjnego, niezacieranego jeszcze we wczesnych redakcjach). Dotyczyłoby to i części rękopisów z pierwszej, ściśle literackiej, warsztatowej partii teki. Wskazywałem interesujące z tego punktu widzenia elementy „Ziga” / Popotudnia w Tirynsie, ale symptomatyczny jest także finał rękopisowej redakcji Ziarna szaleństwa. Zawiera obrazek, co do którego trudno powstrzymać się przed sformulowaniem hipotezy, że miał swój prototyp w scence rzeczywistej: „A po chwili ocknęła się i powiedziała bez sensu: Ojciec każe dawać tylko makaron, ryż a z tego tyję - poskarżyła się niezdarnie”. To dialog zbyt chyba „bez sensu” w kontekście tego, co dzieje się w opowiadaniu, żeby mógł ukazać się w druku, toteż się nie znalazł w ostatecznej redakcji, „bezsensowność” jednak, paradoksalnie, w rękopisie dodaje zapiskowi wiarygodności, jeśli podejrzewać go o charakter dokumentujący rozmowę rzeczywistą.

Niezależnie jednak od tego, czy materiał jest wzięty z jakichś podręcznych notatników, czy może nawet z samych zeszytów dziennikowych; czy ma charakter notatek sporządzanych na gorąco, w dodatku z wyakcentowanym momentem pisania (zwłaszcza Maraton), czy też od początku powstawał jako materiał warsztatowy do pracy przy Opowiadaniach, uważam, że jeśliby dzienniki Kowalskiej miały być kiedyś wydawane w całości, a to niewątpliwie się zdarzy, edytor powinien poważnie rozważyć publikację materiału z tej teki, $\mathrm{w}$ formie aneksu do dziennika. Ma ogromną wartość poznawczą - dokumentarną, refleksyjną, nie mówiąc już o urodzie językowej - i mógłby funkcjonować jako swoiste dopełnienie, by nie powiedzieć: uzupełnienie ${ }^{15}$. Aneks taki rekompensowałby brak w „korpusie podstawowym” wpisów dotyczących bądź co bądź ważnego doświadczenia Kowalskiej.

Myślę tu także o materiałach, co do których trudno orzec, w jakim stopniu są obrazkiem z dnia wędrówki, a w jakim - już gotowym fikcjonalnym tekstem opartym na prototypowym zdarzeniu. Próbki artystyczne to przecież nierzadki komponent materiałów diarystycznych pisarzy i nie sądzę, by druk tych materiałów w publikacji dzienników Kowalskiej - zwłaszcza w formie wydzielonego aneksu - był rażący czy kontrowersyjny. I to nawet w wypadku kolejnych redakcji materiału - takich jak rękopisy Rekrutów paryjskich. Czytelnik więcej zyskałby, niż stracił. Straciłby właśnie na niewydrukowaniu tych sugestywnych, zapraszających do roztrząsań, co najmniej kontekstowych dla dziennika materiałów.

\footnotetext{
15 Nie wiadomo zresztą - do tego konieczne byłyby obszerne studia całej zachowanej spuścizny rękopiśmiennej - czy i w innych materiałach warsztatowych nie ma kart godnych takiego rozpatrzenia publikacyjnego. Obiecujące wydają się na podstawie samej już lektury katalogu Muzeum Literatury (Kordaczuk 2017: 213, 242) zwłaszcza "Wspomnienia i refleksje osobiste k. 34-35, 39" z teczki z wczesnymi redakcjami „Przechadzek humanisty”; ;,Refleksje filozoficzne i etyczne [...]”, ,'Drobne wspomnienia z pobytów wraz z mężem w Selinunte na Sycylii i w Grecji [...]” czy "Wspomnienia o Tadeuszu Mikulskim [...]” z notatników autorki w ML. Por. także notatniki literackie w Ossolineum, nr akc. 240/54. Osobna sprawa to status notatników w spuściźnie Kowalskiej. Nawet jeśli ona sama (?) wydzieliła je ze względu na ich charakter warsztatowy, związany z pracą artystyczną (m.in. przekłady, pomysły literackie), wypada pochylić się nad nimi w przyszłości i zastanowić nad ich niezależnością od dzienników (których zeszyty przecież także noszą tytuły: „Notatki 1949-1950”, „Notatki, październik 1950" - Kordaczuk 2017: 235).
} 


\section{Bibliografia}

\section{Archiwalia}

Kowalska ML 2146 = Kowalska, Anna (1924-1937). [Dzienniki]. Archiwum Anny Kowalskiej (nr inw. ML 2146, t. I: k. luźne, 3 zeszyty, część zeszytu; t. II: zeszyt 7). Muzeum Literatury im. Adama Mickiewicza w Warszawie.

Kowalska ML 2128 = Kowalska, Anna (między 1933-1949). [Opowiadania greckie]. Archiwum Anny Kowalskiej (nr inw. ML 2128). Muzeum Literatury im. Adama Mickiewicza w Warszawie.

[Egzemplarz książki Opowiadania greckie Anny Kowalskiej, wyd. II, 1956]. Księgozbiór Kazimierza Wierzyńskiego (sygn. Wierz 176). Biblioteka Muzeum im. Adama Mickiewicza w Warszawie.

\section{Publikacje}

Bartelski, Lesław Marian 1957. „Z Anną Kowalską rozmawia Lesław Bartelski”. Nowa Kultura 31: 3,7 .

Bart[elski], L[esław] M[arian] 1959. „Historia i współczesność”. Świat 31: 18.

Bratkowski, Stefan 1960a. „Fiasco nagrody Hemingway'a”. Dookoła Świata 5: 10-11.

- 1960b. „Jeszcze raz Hemingway”. Dookoła Świata 9: 2.

Dąbrowska, Marja [!] 1960. „List od Marii Dąbrowskiej”. Dookoła Świata 8: 2.

Garlicki, Andrzej 2008. „Uzupełniając Marię Dąbrowską”. Polityka, www.polityka.pl/tygodnikpolityka/kultura/ksiazki/277550,1,recenzja-ksiazki-anna-kowalska-dzienniki-1927-1969. $\operatorname{read}[23.01 .2018]$.

Hartwig, Julia 2008. „Przeciw sobie. O Dziennikach Anny Kowalskiej”. Przedmowa do: Anna Kowalska. Dzienniki 1927-1969. Wybrał, z rękopisu do druku przygotował, przypisami opatrzył Paweł Kądziela. Przedmowa Julia Hartwig. Warszawa: Iskry.

Jackiewicz, Aleksander 1950. „Książki wczorajsze”. Kuźnica 7: 7.

Jastrun, Mieczysław 1978. Podróż do Grecji. Kraków: Wydawnictwo Literackie.

Kijowski, Andrzej 1950. „Przygody archeologa”. Wieś 9: 5.

Kordaczuk, Wiesława (oprac. i red.) 2017. Katalog rękopisów Muzeum Literatury im. Adama Mickiewicza w Warszawie. T. 5: Sygnatury 2001-2180. Archiwa Marii Dąbrowskiej, Anny Kowalskiej, Stanistawa Stempowskiego. Warszawa.

Korzeniewska, Ewa (red.) 1964. Kowalska Anna. Hasło w: Stownik wspótczesnych pisarzy polskich. Oprac. zespół pod redakcją ... T. 2. Warszawa: Państwowe Wydawnictwo Naukowe.

Kowalscy, Anna i Jerzy 1937. „Dwie sztuki”. Sygnaty 34: 7.

Kowalska, Anna 1938. „Rekruci z wyspy Paros”. Filomata 100: 438-453.

- 1956. Opowiadania greckie. Wyd. 2. Warszawa: Czytelnik.

- 1958. Fragmenty dzienników. W: Anna Kowalska. Nimfa. Warszawa: Państwowy Instytut Wydawniczy.

- 1966. Trzy boginie. Opowiadania. Warszawa: Czytelnik.

- 1975. Czas oswojony (przedmowa). W: Maria Dąbrowska. Przygody człowieka myślącego. T. 1. Warszawa: Czytelnik.

- 2008. Dzienniki 1927-1969. Wybrał, z rękopisu do druku przygotował, przypisami opatrzył Paweł Kądziela. Przedmowa Julia Hartwig. Warszawa: Iskry. 
Kowalski, Jerzy 1936. „Dziennik podróży greckiej”. Sygnały 23: 6.

- 1937. „Byłem na Eubei”. Sygnaty 25: 5.

Lichniak, Zygmunt 1950. „Dramat fatalistyczny”. Dziś i Jutro 8: 7.

„Nagroda literacka Hemingway'a” 1959. Tygodnik Powszechny 51: 6.

Rodak, Paweł 2011. Między zapisem a literaturą. Dziennik polskiego pisarza w XX wieku. Warszawa: Wydawnictwa Uniwersytetu Warszawskiego.

Speina, Jerzy 1998. Literatura w perspektywie psychologii. Studia i szkice o polskiej prozie narracyjnej Dwudziestolecia i jej recepcji krytycznoliterackiej. Wydawnictwo Naukowe UMK.

- 2014. Reminiscencje spartańskie w poezji polskiej XX wieku. W: Małgorzata Borowska, Maria

Kalinowska, Jerzy Speina, Katarzyna Tomaszuk (red.). Sparta w kulturze polskiej. Cz. 1: Model recepcji, spojrzenie europejskie, konteksty greckie. Warszawa: Wydawnictwo Naukowe Sub Lupa.

Z[awadzka], J[oanna] 1996. Kowalska Anna. Hasło w: Wspótcześni polscy pisarze i badacze literatury. Stownik biobibliograficzny. Oprac. zespół pod red. Jadwigi Czachowskiej i Alicji Szałagan. T. 4. Warszawa: Wydawnictwa Szkolne i Pedagogiczne.

Żukrowski, Wojciech 1950. „W zwierciadełku”. Tygodnik Powszechny 32: 6. 